821.111(73).09-31 Updike J.

https://doi.org/10.18485/bells.2019.11.6

\author{
James Plath* \\ Illinois Wesleyan University \\ Bloomington, IL \\ Unites States of America
}

\title{
JOHN UPDIKE'S THE CENTAUR AND THE ARTIST DIVIDED
}

\begin{abstract}
George Hunt observed that often the central character in an Updike novel is an unsuccessful or failed artist, a propensity that began in 1963 with Peter Caldwell in The Centaur. The main character, Caldwell/Chiron, is both human and centaur, and all of the characters have mythic identities, including Caldwell's adult son, Peter, who narrates the novel and is assigned the role of Prometheus. Yet, because Peter is torn between abstract expressionist ambitions and mimetic inclinations that underscore a love of detail, he is as much of a centaur, metaphorically speaking, as the elder Caldwell, and an examination of his divided artistic self further illuminates Updike's declaration that "the book as well as the hero is a centaur."
\end{abstract}

Keywords: The Centaur, artist divided, mythology, identity

\footnotetext{
E-mail address: jplath@iwu.edu
} 
"The ordinary man puts up a struggle against all that is not himself, whereas it is against himself, in a limited but all-essential field, that the artist has to battle... Every true artist regards himself, alternatingly or simultaneously, as what he is and also as a failure."

Andre Malraux (1953: 344)

John Updike once told The Paris Review, "My first thought about art, as a child, was that the artist brings something into the world that didn't exist before, and that he does it without destroying something else. A kind of refutation of the conservation of matter. That still seems to me its central magic, its core of joy" (Plath 1994: 45). Yet, as George Hunt notes, often the central character in an Updike novel is an unsuccessful or failed artist (Hunt 1980: 153), a propensity that began in 1963 with The Centaur's Peter Caldwell.

The Centaur was Updike's tribute to his father, Wesley, a funny and popular teacher at Shillington High School who nonetheless had problems controlling his classes. Students liked him but also disrespected him, to use the current vernacular. In the novel, George Caldwell is not only a science teacher but also Chiron, the centaur. In fact, all the main characters in the novel have mythic counterparts, including Peter, who at one point lies on "his rock" (175) and we begin to understand that he is also Prometheus, who tried to help mankind by giving them fire, and whom Zeus subsequently punished by chaining him to a rock so an eagle could eat his liver, day after day. Peter, who appropriately lives in Firetown and daily feels a growing dread of his father's mortality eating away at him, shares the narrative duties with an omniscient narrator that we come to realize is also Peter. The novel alternates between Peter's and George's points of view and between mythic and realistic chapters. Without the mythic component added to an otherwise essentially realistic non-chronological narrative, Updike has said that there would be no book. "It seemed to me to fit a kind of experience that I'd had: my father's immersion in the world of Christian morality, in trying to do the right thing and constantly sacrificing himself, always going off to church meetings, and yet complaining about it all the time. There was an ambivalence that seemed to make him very centaur-like." 
The novel's title could have been plural. While Updike assigns Peter the mythological role of Prometheus, the fact that Peter is a divided artist also makes him as much of a centaur-metaphorically speaking-as the elder Caldwell. Peter is, by his own admission, "an authentic second-rate abstract expressionist" (102-103), though ironically he is drawn not to the large canvases upon which he struggles to create non-representational images, but to life's small details that show how much he exalts in the world of recognizable objects and figures.

On the simplest level, as Jack De Bellis summarizes, Peter is "a dual figure" insomuch as he is both a Pennsylvania high school student and also a twenty-seven-year-old New York-based artist "whose recollections of his fifteen-year-old self form the narrative" (De Bellis 2000: 85). What complicates Peter's story and links it to Updike's underlying motif of death, however, is the other duality - the mythic component-for it is the classically trained artist, Peter, who is a visionary when it comes to "painting" his father and the other residents of Olinger in glorious detail as gods and mythical characters. Yet, Peter fails at creating an image vocabulary that derives exclusively from his imagination, and his "vast canvases-so oddly expensive as raw materials, so oddly worthless transmuted into art-with sharp rectangular shoulders hulk into silhouette against the light" (268). This passage from the text illuminates the ironic reason why Peter is a failed abstract expressionist: he sees the blank canvases and raw materials that mock him as having "sharp rectangular shoulders." In other words, he sees a recognizable human form in those blank canvases because his orientation as an artist is to "paint" using familiar images from the world around him. His talent is not abstraction, but in pictorially and representationally describing his father's world on a grand scale that links humans to the gods in a "painted" narrative that's worthy of the enormous history paintings by Old Masters. It's precisely because his ambition and natural talent and orientation do not line up that he is divided as an artist and frustrated by his inability to achieve the artistic goal he's set for himself. Frustrated by art this way, Peter is himself a centaur, even as picturing these mythic/ realistic images of his father and community make him, quite literally, the creator of centaurs. As Updike described the novel, "It's an experiment very unlike that of Ulysses, where the myth lurks beneath the surface of the natural events. In a way the natural events in my book are meant to be a kind of mask for the myth" (Plath 1994: 51). Updike himself is an artist divided, for his first ambition was to become a graphic artist rather than a 
writer. "I am a sort of frustrated painter," he told Jeff Campbell, "or rather I have painted a bit and was told I have a very good sense of composition. So maybe I see the book as a canvas with things disposed in it" (Plath 1994: 91-92).

As a youth, Peter was a landscapist, which Vermeer contemporary Samuel van Hoogstraten derisively referred to as "common footmen in the Army of Art" (Fuchs 1978: 104). Peter is sensitive to such dismissive assessments, for he notices, "In the narrow space of kitchen wall between the two doorways hung a painting I had done of our back yard in Olinger. My mother's shoulder eclipsed it" (58). In the time of Vermeer, the artist that Updike and Peter most admire, the hierarchy of genres was an accepted aesthetic in which landscape paintings and still lifes were the least respected. Even Vermeer's genre paintings of daily human activity were regarded as only slightly more serious and important. In this classical hierarchy, the most praiseworthy genre was history paintingthe recording of religious, historical, allegorical, or mythological events that involved human interaction and strife on a grand scale. Although the hierarchy of genres prevailed until the start of the 20th century, by the time an adult Peter enters his chosen profession the aesthetic has radically changed (Encyclopedia of Art 1). As Updike told one interviewer, "The pictorial arts seem to me to be the heroic modern arts, somehow, and also they're the most lucrative, it turns out" (Plath 1994: 218). And the type of art that was getting all the attention, the art that was appearing on giant canvases as if to shout their own importance, was non-representational abstract expressionism-an American-born style and movement so bold, powerful, and original that New York City displaced Paris as the center of the western art world. As Updike once confessed, "I was greatly moved in obscure fashion by Abstract Expressionism, the giant canvases of which were still fresh on museum walls when I was a young writer in the fifties" (LTR 1). It is no wonder, then, that Peter set out to become an abstract expressionist himself. The problem is that he is more naturally inclined to paint representational art-images that have a recognizable visual counterpart in the actual world-rather than the strictly imaginative nonrepresentational art. Like George Caldwell, whom we see divided between the contemporary and mythic worlds, Peter lives in both the contemporary world of abstract expressionists and the classical world of art that still exalted paintings of human interaction that also celebrated the mythology of humankind. 
Peter's love of detail and the play of light is evident throughout the narrative. As he watches his father in the snow at night he notices that the "streetlight touched with a row of steady flecks the curve of his knit cap: the way Vermeer outlined a loaf of bread" (149). Peter not only tends to see things as Vermeer did, he is also emotionally connected to Vermeer's way of seeing-so much so that after a 4-H Club meeting his mother forced him to attend, Peter would "plunge at home into my book of Vermeer reproductions like a close-to-drowned man clinging to the beach" (74). Details excite and reinvigorate him. Recalling a drive with his father in a snowstorm, Peter draws energy from the world around him that enables him to continue his "painted" narrative recollection: "Vases and burnished furniture stood upright around me. On a stiff tablecloth a loaf of sugary bread lay sequined with pointillist dabs of light" (78). Peter continues, "Among these images which the radio songs brushed in for me the one blank space was the canvas I was so beautifully, debonairly, and preciously covering. I could not visualize my work; but its featureless radiance made the center of everything as I carried my father in the tail of a comet through the expectant space of our singing nation" (78). Prior to this passage Peter had admitted to being a failed abstract expressionist, but songs on the radio help him to remember his past with the same kind of detail as his artistic hero, and that descriptive detail generates a burst of razzle-dazzle poetics-more word painting, if you will—that eventually leads him to feel more positive about the blank canvas in front of him.

There is another complication, though. As Updike writes, "I think that initially art was tied in with theology and has to do with an ideal world: the artist is in some way a middleman between the ideal world and this, even though our sense of the ideal... is at present fairly dim" (Plath 1994: 51-52). In The Centaur, readers witness Peter grappling not only with figurative versus non-figurative art, but also with the implied dialectic between that which is real and that which is only an illusion or imperfect copy of an ideal that exists in a different realm.

In his fiction, Updike has often alluded to or specifically mentioned Plato's famous analogy of the cave and its concept of shadows versus ideal forms. In Plato, shadows are the objects of the world, a false reality, and people are imperfect copies of ideals that lie in the realm of pure spirit. In Updike, a similar sense of the world's shadowy, insubstantial nature is held in sharp contrast to the world of ideals, though the unique mythic/ contemporary nature of The Centaur adds another layer of complexity. In 
the mythic chapter, a three-pointed arrow flies through the air, piercing Chiron/Caldwell's ankle; in the contemporary version, it's a paper airplane that flies through the air-one heavy and dark, the other airy and light (4, 41). Likewise, while the class laughs at Chiron/Caldwell after he's shot and limping, "Caldwell's strange silhouette"-that is, his heavy, dark, shadow self-"took on dignity" (6). Peter is sensitive to shadow as Other, for when his father picks up a dirty and rough-mannered hitchhiker and starts talking to the man about his son, Peter remarks, "I vividly resented that he should even speak of me to this man, that he should dip the shadow of my personality into this reservoir of slime. That my existence at one extremity should be tangent to Vermeer and at the other to the hitchhiker seemed an unendurable strain" (83). Later, on another drive, when George tries to get their stalled car up a hill in a snowstorm, Peter sees/says, "My father's shadow hurriedly tried all the gears" (149). And when his father's clenched fists tighten on the steering wheel, defeated once again by life, "it frightens Peter to see his father's silhouette go out of shape this way" as the "snow holds them fast in its phantom grip" (260).

In perhaps the most revealing reference to shadows in relation to light, when the adult Peter is lying next to his black mistress, he thinks back to a time when he was a teenager waking in the morning from a dream in which Penny, a classmate he found attractive, had been with him by a tree. "The top buttons of her blouse were undone," he recalls, and it's clear to readers that Peter was trying to finish the dream while masturbating and recalling an earlier incident when he found his hand "between her warm thighs which were pressed together; it seemed to dawn on her slowly that my hand was there, for a minute passed before she begged, 'Don't,' and when I withdrew my hand, she looked at me like that. Only that was in shadow and this was in brilliant light" (50). Peter's reimagined daydreams are more brilliant than reality itself. His remembered sexual incident with Penny occurs in darkness, while the reimagined scene unfolds in "full light," made more real by a corresponding fullness of language-so real that the "pores on her nose showed" before she became "unnaturally still" as Peter's mother interrupts him. But the lesson is clear: Art is superior to actuality, associated with light rather than darkness and shadow-with the ideal forms that Plato described, rather than the shadows on the wall of the cave. That notion is reinforced later in the novel when Peter thinks,

I had been admiring a section of lavender shadow under the walnut tree in my painting of the old yard. I had loved that tree; 
when I was a child there had been a swing attached to the limb that was just a scumble of almost-black in the picture. Looking at this streak of black, I relived the very swipe of my palette knife, one second of my life that in a remarkable way had held firm. It was this firmness, I think, this potential fixing of a few passing seconds, that attracted me, at the age of five, to art (61-62)

In this transcendent passage, shadow acquires the same sense of solidity and realness as light. Art renders both more solid, more permanent. As Terrence Doody notes in his essay on reification in Updike, "to Updike and to his characters haunted by death, things offer a stability that may not amount to immortality, but that does seem firmer than human life" (219). Yet, while things themselves can break or deteriorate, art has the potential to extend life. In The Centaur, when Chiron and Venus talk about the gods, Venus quips that they are "Perfect only in our permanence." Art for Updike and Peter is Olympian, a chance to preserve seconds, moments, lives. Though Peter's desire to become a painter "embarrassed" his father (89), ironically that desire may have been partly fueled by a desire to keep George Caldwell alive, to give him the kind of immortality that a young boy thought his father deserved. But it is also ironic that Peter keeps him alive not by abstraction, but by painting a narrative rich and textured as anything his childhood artistic heroes painted. Though young Peter begins as a painter of landscapes and then stalls as a non-representational artist, he finally succeeds in word-painting a portrait of his father that would have been considered the highest achievement in the old hierarchy of genres: a history painting of his father and others from this small Pennsylvania town drawn mythically, on a grand scale.

Eikons, or images, according to Plato, are the shadows of reality. But a more recent philosopher, Paul Ricoeur, believes quite the opposite of what Plato implies to be true for art:

Far from yielding less than the original, pictorial activity may be characterized in terms of an "iconic augmentation," where the strategy of painting, for example, is to reconstruct a reality on the basis of a limited optic alphabet. This strategy of contraction and miniaturization yields more by handling less. In this way, the main effect of painting is to resist the entropic tendency of the ordinary vision-the shadowy image of Plato-and to increase the meaning of the universe by capturing it in the network of its abbreviated signs. (Ricoeur 1976: 40-41) 
Updike, it seems, would agree. Meaning is enhanced through the pictorial appropriation of recognizable signs-memesis-rather than abstraction. Because Peter's daydreams are more vivid than the reality which surrounds him, the implication is that for Updike the "ideal" forms exist in the world of art, the world of the vivid and active imagination, rather than, or possibly in addition to, the spiritual realm of other-worldness implicit in the analogy of Plato's cave.

When Peter recalls boyhood trips to the local museum, he remembers that the main floor, given over to scientific and anthropological exhibits, "always filled me with dread" (267). However,

The second floor was devoted to art, mostly local paintings that, however clumsy and quaint and mistaken, nevertheless radiated the innocence and hope, the hope of seizing something and holding it fast, that enters whenever a brush touches canvas... (267)

Peter thinks how "when darkness came, and the mummy and the Polynesian masks and the glass-eyed eagles were sealed in shadow," this second-floor art room would be "lit by the moon through the skylight above" (268). That lower-level darkness and shadow versus higher-level light obviously parallels the initial description readers were given of George Caldwell, whose top half is "all afloat in a starry firmament of ideals" and whose lower half is associated with death, evocative of the plodding existence Caldwell experiences as a weary educator, where "heavily sunk in a swamp where it must, eventually, drown" (4).

Like his son, George Caldwell is unsettled by blankness. Rather than a gigantic canvas, though, it's his students that disturb him: "I look at those dumb blank faces every day and it reminds me of death," he says. Both father and son valiantly try to dodge the "arrows of shadow" (201) that come at them. Blankness. Shadows. Death. The three are linked in Updike's aesthetic world— the polar opposite of detail, light, and the kind of immortality that art can provide. In a lecture on science to his students, George Caldwell explains what came after the Big Bang: "The universe became totally dark. And the dark matter-dust, planets, meteors, junk, garbage, old stones-still greatly outweighs the luminous matter" (39). In The Centaur, both George and Peter Caldwell seek the light, the substantial, the real-though their respective two halves and ontological questions blur the line, as the Karl Barth epigram at the beginning of the novel suggests: 
Heaven is the creation inconceivable to man, Earth the creation conceivable to him. He Himself is the creature on the boundary Between heaven and earth.

The artist is more sensitive to this boundary than the common person, and the whole idea of boundaries and thresholds seems to have been what attracted young Peter to Penny in the first place:

I believe it was these incongruities...

These soft and silent clashes like the reticulating ripples hinting in the flow of a stream of irregular depths, that made

her beauty for me; this delicate irresolution of feature held out the possibility of her being worthy of me. And made her seem always a bit unexpected. (117)

While Peter may be serious in his attempt to paint a word portrait of his father on a grand mythological scale, and while he assigns everyone in his small town mythic roles as Greek gods and goddesses, the near-comic action of the novel is so incongruous that it nearly undermines his serious artistic attempts. History painting usually featured major historical or biblical figures engaged in actions that were high dramas, often hard-fought battle victories. In The Centaur, the action takes place over three days, but rather than a narrative of biblical proportions, what happens is both mundane and comical: George Caldwell is struck by an arrow, he has it removed by a local mechanic, he tries to teach his out-of-control science class, he is propositioned by a gym teacher, he gives a favorite student the answers to a test, he tries to coach the swim team, he tracks down missing basketball game tickets, he and his son get caught in a blizzard, they pick up a grimy hitchhiker who steals his gloves, George visits the dentist to have a tooth pulled, and he has a cancer scare. None of these events would have been a worthy subject for a history painting in the time of the Old Masters, but they would have been fitting subjects for Vermeer's genre paintings of daily human activity. Peter, whose hero is Vermeer, is so influenced by the artist that he has become a disciple, however accidental it may be.

It would be tempting to conclude that Peter should abandon his quest to be an abstract expressionist and follow his strength and inclinations in order to create traditional representational art, but that goes against the 
divided structure of The Centaur. And Updike's fiction has displayed such a tendency toward the dialectic that to seek such an easy resolution in Updike is, as Peter senses of his desire to paint in the manner of abstract expressionists, like straining to say the unsayable.

\section{References}

De Bellis, J. (2000). The John Updike Encyclopedia. Westport, Conn.: Greenwood Publishing.

Doody, T. A. (1979). Updike's Idea of Reification. Contemporary Literature, 20:2, 204-220.

Fuchs, R. H. (1978). Dutch Painting. London: Thames and Hudson.

Hierarchy of the Genres (c. 1669-1900). Encyclopedia of Art. (14 June 2018) <http://www.visual-arts-cork.com/history-of-art/hierarchy-ofgenres.htm $>$.

Hunt, G. W. (1980). John Updike and the Three Great Secret Things: Sex, Religion, and Art. Grand Rapids, Mich.: William B. Eerdmans Publishing Company.

Malraux, A. (1953). The Voices of Silence. New York: Doubleday \& Company.

Plath, J. (ed.) (1994). Conversations with John Updike. Jackson, Miss.: University Press of Mississippi.

Ricoeur, P. (1976). Interpretation Theory: Discourse and the Surplus of Meaning. Fort Worth, Texas: Christian University Press.

Updike, J. (1970). The Centaur. New York: Alfred A. Knopf.

—. Letter to the author. 24 May 1986.

—. (1975). Picked-Up Pieces. New York: Alfred A. Knopf.

Received: 14 June 2018

Accepted for publication: 28 December 2018 
Џејмс Плат

КЕНТАУР ЏОНА АПДАЈКА И ПОДЕЉЕНИ УМЕТНИК

\section{Сажетак}

Џорџ Хант је приметио да је централни лик у Апдајковом роману неуспешан или разочаран уметник, тенденција коју је почео да показује 1963. са Питером Колдвелом у Кентауру. Главни лик, Колдвел/Чирон, истовремено је људско биће и кентаур, и сви ликови имају митске идентитете, укључујући Колдвелог одраслог сина, Питера, који је наратор и коме је дата улога Прометеја. Ипак, како је Питер разапет између апстрактних експресионистичких амбиција и миметичких склоности које наглашавају љубав према детаљу, он је подједнако кентаур, метафорички речено, колико и старији Колдвел, и испитивање његовог подељеног уметничког бића још више осветљава Апдајкову изјаву да је „књига као и јунак кентаур“.

Кључне речи: Кентаур, подељени уметник, митологија, идентитет 